
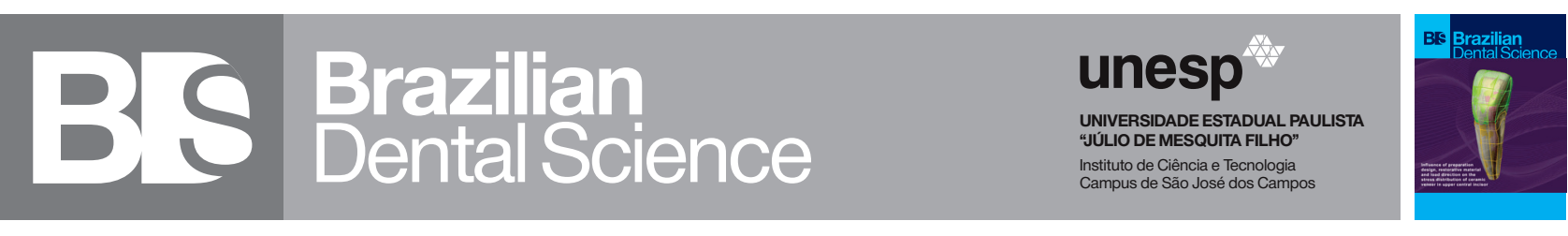

\title{
Effect of Black and Green Tea on Salivary pH: a Double Blinded Cross-Over Study
}

\author{
Efeito do Chá Preto e Verde no pH Salivar: um Estudo Duplo Cego Cross-Over \\ Masoomeh SHIRZAIY ${ }^{1}$, Zohreh DALIRSANI ${ }^{2}$, Javid DEHGHAN HAGHIGHI ${ }^{3}$ \\ 1 - Oral and Dental Diseases Research Center, Zahedan University of Medical Science, Zahedan, Iran. \\ 2 - Oral and Maxillofacial Diseases Research Center, Mashhad University of Medical Sciences, Mashhad, Iran. \\ 3 - Department of Community Medicine, School of Medicine, Zahedan University of Medical Sciences, Zahedan, Iran.
}

\begin{abstract}
Background: Some herbal products could affect on salivary $\mathrm{pH}$ and prevention of dental caries. Tea consumption has inhibition effects on some oral bacteria. Objective: The aim of this study was to evaluate the effect of green and black tea on salivary pH. Material and Methods: In this double blinded cross-over trial, salivary samples of 50 healthy male students of Zahedan Faculty of Dentistry, aged 20-22 years old were collected for evaluation of salivary $\mathrm{pH}$. All volunteers were asked to consume commercially black tea on the first day and then saliva samples were collected before drinking tea and immediately after drinking tea and 5 and 10 minutes after tea consumption. With replacing consumption of green tea, at the second day, saliva samples were collected again. Then the salivary $\mathrm{pH}$ was estimated with a digital $\mathrm{pH}$-meter. Data were analyzed through independent t-test and paired samples t-test. Results: Mean salivary $\mathrm{pH}$ before and after green tea consumption were $7.15 \pm 0.05$ and 7.56 \pm 0.09 , respectively, which showed a remarkable difference $(\mathrm{p}<0.001)$. It was $7.14 \pm 0.05$ and $7.51 \pm 0.10$, respectively, for black tea, with significant difference $(\mathrm{p}<0.001)$. Mean salivary $\mathrm{pH}$ after green tea consumption was significantly higher than black tea $(p=0.006)$. Conclusion: Both green and black tea intake led to a significant rise in salivary $\mathrm{pH}$, which was higher after green tea consumption compared to black tea. This study suggests the beneficial effects of drinking tea in providing an alkaline environment in oral cavity.
\end{abstract}

\section{KEYWORDS}

Black tea; Green tea; Saliva; pH.

\section{RESUIMO}

Introdução: Alguns produtos à base de plantas podem afetar o pH salivar e a prevenção da cárie dentária. $\mathrm{O}$ consumo de chá tem efeitos inibidores sobre algumas bactérias orais. Objetivo: O objetivo deste estudo foi avaliar o efeito dos chás verde e preto sobre o $\mathrm{pH}$ salivar. Material e Métodos: neste estudo duplo-cego cruzado, amostras salivares de 50 estudantes saudáveis do sexo masculino da Faculdade de Odontologia de Zahedan, com idades entre 20-22 anos, foram coletadas para avaliação do $\mathrm{pH}$ salivar. Todos os voluntários foram solicitados a consumir chá preto comercial no primeiro dia e, em seguida, amostras de saliva foram coletadas antes de beber o chá, imediatamente após beber o chá, 5 e 10 minutos após o consumo do chá. Alternando com o consumo do chá verde, no segundo dia, as amostras de saliva foram coletadas novamente. Em seguida, o pH salivar foi estimado com um medidor de $\mathrm{pH}$ digital. Os dados foram analisados por meio de teste $\mathrm{t}$ independente e teste $\mathrm{t}$ de amostras pareadas. Resultados: $\mathrm{O}$ pH salivar médio antes e após o consumo de chá verde foi de 7,15 $\pm 0,05$ e 7,56 \pm 0,09 , respectivamente, o que apresentou uma diferença notável ( $p<0,001)$. Foi de 7,14 \pm 0,05 e 7,51 \pm 0,10, respectivamente, para o chá preto, com diferença significativa ( $\mathrm{p}<0,0001)$. O pH salivar médio após o consumo de chá verde foi significativamente maior do que o chá preto $(\mathrm{p}=0,006)$. Conclusão: $\mathrm{A}$ ingestão de chá verde e preto levou a um aumento significativo no $\mathrm{pH}$ salivar, que foi maior após o consumo de chá verde em comparação com o chá preto. Este estudo sugere os efeitos benéficos de beber chá em fornecer um ambiente alcalino na cavidade oral.

\section{PALAVRAS-CHAVE}

Chá preto Chá verde; Saliva; $\mathrm{pH}$. 


\section{INTRODUCTION}

$\mathrm{D}$ uring development of dental caries, acid produced by some oral bacteria including Streptococcus mutans, Actinomyces spp. and Lactobacillus spp. dissolves the hydroxyapatite of the teeth and leads to cavity formation. After that, microorganisms gradually penetrate to dental pulp and cause tooth pain [1,2]. It seems that any factor, which could change the local environment condition and oral microflora; leads to biofilm dysbiosis and increases cariogenic bacteria, which contribute to the development of dental caries [3].

Despite some progress in dentistry science for replacement of dental tissue, completed replacement of primary tissue is not possible and prevention plays an important role in maintenance of the dental tissue.

Saliva through re-mineralization of enamel is effective in control of causative factors of dental caries. Saliva has enough calcium, phosphorous and fluoride and its buffering capacity has a huge ability to neutralize the acidic environment and control of teeth decay. Salivary $\mathrm{pH}$, which is an indicator for hydrogen ion concentration, is about 6.7 to 7.4. After breaking down the carbohydrate by some oral bacteria, the salivary $\mathrm{pH}$ decreases and acidic environment leads to demineralize the dental enamel [4]. Therefore, oral fluid $\mathrm{pH}$ is a determinate factor for dental caries, as acidic $\mathrm{pH}$ increases the possibility of dental caries $[5,6]$.

Tea is a favorite drinking worldwide. According to processing of development of tea leaf, tea categorized into three groups; black (fermented), green (non-fermented) and oolong (semi-fermented). In Green tea the fermentation process is the least and has a lot of catchins, which is known as flaventriol [7]. When the rate of activity of polyphenol oxidase and the rate of fermentation increases, the odor and color and other properties of this plant change and black tea is produced $[7,8]$.

Tea is produced from the fresh leaves of Camellia sinensis and consists of several active bio components including xanthine, theobromine, flavonoids and polyphenols [9]. Polyphenols consist of catchins and theaflavin are the major components of the tea, which are responsible for potential effects of this plant on health [10].

Green tea has anti-oxidant, antiinflammatory and anti-cancerous effects [11]. Daily usage of tea decreases the risk of some cancers, mortality rate of cardiovascular and cerebrovascular diseases and cancers and improves anti-oxidant system [12-14].

In some studies, preventive effects of xylitol, fluoride, casein components, phospholipids of green tea are proved via $\mathrm{pH}$ changes of the saliva [15].

There are some evidences based on the effect of green tea on decrease of dental caries in the human and animals. Green tea could remarkably decrease the Streptococcus mutans levels in the saliva and consequently reduce the possible of caries [11]. On the other hand, epigallocatechin-3-gallate (EGCG) extract of green tea inhibits lactate dehydrogenase enzyme and reduces the production of acid after sugar consumption and leads to decrease the development of caries [16]. Furthermore, polyphenols could prevent from attachment of oral bacteria to the dental surfaces [17].

Polyphenolic compounds of tea have a potent anti-glucosyltransferases activity, which decreases the production of insoluble glucans, as an effective factor in bacterial adhesion and consequently acid production. Therefore, it is logical to claim that tea could increases oral $\mathrm{pH}$ $[3,18]$. In recent years, researchers have made efforts to synthesis non-cariogenic products and identify potentially anti-cariogenic natural agents for better control of dental caries[3]; however, few studies performed on effects of green and black tea on salivary $\mathrm{pH}$. This study aimed to compare the effects of consumption of green and black tea on salivary $\mathrm{pH}$.

\section{METHODS}

This project was approved by ethical 
committee of Zahedan University of Medical Sciences with ethical code of 93.4.1223. The sample size was determined as 40 subjects based on the similar published manuscript [19]. Consecutive sampling technique was employed for the present study. Dentistry students of Zahedan Faculty of Dentistry were enrolled in this double blinded cross-over study, if they met inclusion criteria. All 20-22 years old male students, who had a minimum of 20 permanent teeth and a maximum of 2 decayed teeth, after signing informed consent form (62 persons), were included in this study.

Exclusion criteria were: systemic diseases, drug consumption during 3 past months (3 subjects), chronic or active periodontal or dental infections (3 subjects), inflammatory oral infection, salivary gland disorders, history of radiotherapy, smoking (5 subjects), drug abuse, and using orthodontic plaque (1 subject). Finally, 50 persons were enrolled in this study.

All patients were under oral examination on the dental unit by a dentistry student under exact supervision of an oral medicine specialist. DMFT (Decayed, Missing, Filled Teeth) of all subjects were measured.

The Commercially available black and green tea for this study belonged to Ceylon Zarrin Tea, London. The tea was prepared based on instruction of the faculty. For preparation of black tea, 2 gr of black tea was purred into 150 $\mathrm{mL}$ boiling water $\left(100^{\circ} \mathrm{C}\right)$, after 3 minutes, it was ready for drinking. As well as for green tea, 3 gr of green tea was purred into $150 \mathrm{~mL}$ hot water $\left(70^{\circ} \mathrm{C}\right)$, after 3 minutes, it was prepared for drinking. After that, both prepared teas were filtered and one of the research team members numbered them.

On the study day, all subjects brushed their teeth with brush oral B (soft type) and tooth paste Colgate Total, 45 minutes after eating breakfast.

Between 9-11 a.m., saliva samples were collected through spitting method, one hour after breakfast and 15 minutes after brushing. Every subject was asked to bend his head forward and spit his saliva into laboratory tube (No:1), every 60 seconds for 2-5 minutes [20].

On the first day of study, after collecting the initial salivary samples, every subject drinks $30 \mathrm{~mL}$ tea (code.1), saliva samples were collected into tubes (No: 2-4 for every subject), before, immediately and after 5 and 10 minutes after drinking tea. On the next day, all stages, mentioned above, repeated for the tea (code.2). For making the subjects blind to which tea they are drinking, the prepared teas were served in the dark glasses.

Salivary $\mathrm{pH}$ for all samples was immediately assessed by digital $\mathrm{pH}$ meter (Isolab Laborgerate $\mathrm{pH}$ meter, Wertheim, Germany). The $\mathrm{pH}$ meter was calibrated, before assessment of the samples with buffering solutions form (Hi Media). For evaluation of $\mathrm{pH}$, the electrode of $\mathrm{pH}$ meter was immersed into the samples and $\mathrm{pH}$ was reported. This test was repeated twice for each sample.

The researcher, who assessed the salivary $\mathrm{pH}$, was blind to the type of tea.

The data were entered into software SPSS (ver.21) for statistical analysis. KolmogorovSmirnov normality test was employed to assess normal distribution of the quantitative variables. For comparison of the quantitative data with normal distribution independent t-test and paired samples t-test were used. The significance level for these statistical tests was considered as 0.05 .

\section{RESULTS}

In this study, fifty 20-22 -years male students with the mean age of $21.1 \pm 0.90$ years were entered into the study. The mean DMFT score for the subjects was $2.70 \pm 1.01$.

Mean salivary $\mathrm{pH}$ before and 10 minutes after drinking green tea were $7.15 \pm 0.05$ and $7.36 \pm 0.09$, respectively (table I and figure 1 ). Paired samples t-test showed that there was significantly different between salivary $\mathrm{pH}$ before and immediately after consumption, and 5 and 10 minutes after drinking green tea $(0<$ 001) (table I and figure 1). 
Table I - Comparison of mean salivary $\mathrm{pH}$, before and after drinking green tea

\begin{tabular}{|c|c|c|}
\hline Time & Mean \pm SD & p-value* \\
\hline Before drinking & $7.15 \pm 0.050$ & \multirow{5}{*}{$0<001$} \\
\hline Immediately after drinking & $7.78 \pm 0.09$ & \\
\hline 5 min after drinking & $7.55 \pm 0.10$ & \\
\hline 10 min after drinking & $7.36 \pm 0.09$ & \\
\hline $\begin{array}{c}\text { Mean of } 0,5 \text { and } 10 \text { minutes after } \\
\text { drinking }\end{array}$ & $7.56 \pm 0.09$ & \\
\hline
\end{tabular}

${ }^{*}$ Paired samples t-test
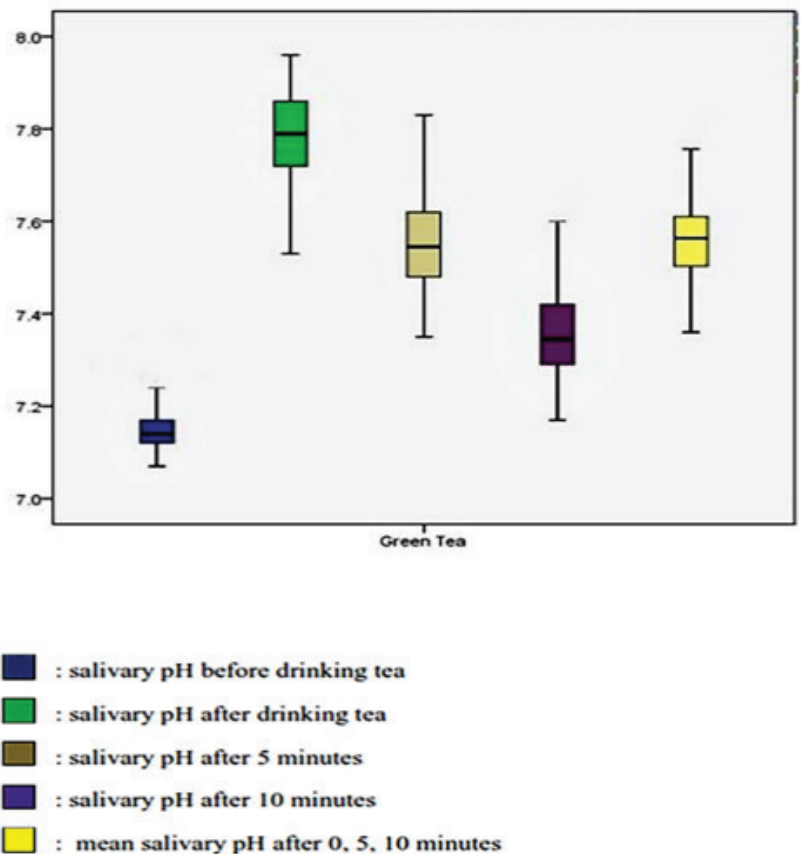

Figure 1- box plot of mean salivary $\mathrm{pH}$ before and after drinking green tea.

Mean salivary $\mathrm{pH}$ before and 10 minutes after drinking black tea were $7.14 \pm 0.05$ and $7.31 \pm 0.10$, respectively (table II and figure 2). Paired samples t-test showed that there was significantly different between salivary $\mathrm{pH}$ before and immediately after consumption, and 5 and 10 minutes after drinking black tea $(0<$ 001) (table II and figure 2).
Table II - Comparison of mean salivary $\mathrm{pH}$, before and after drinking black tea

\begin{tabular}{|c|c|c|}
\hline Time & Mean \pm SD & p-value ${ }^{\star}$ \\
\hline Before drinking & $7.14 \pm 0.050$ & \multirow{5}{*}{$0<001$} \\
\hline Immediately after drinking & $7.71 \pm 0.12$ & \\
\hline 5 min after drinking & $7.50 \pm 0.12$ & \\
\hline 10 min after drinking & $7.31 \pm 0.10$ & \\
\hline $\begin{array}{c}\text { Mean of } 0,5 \text { and } 10 \text { minutes after } \\
\text { drinking }\end{array}$ & $7.51 \pm 0.10$ & \\
\hline
\end{tabular}

* Paired samples t-test
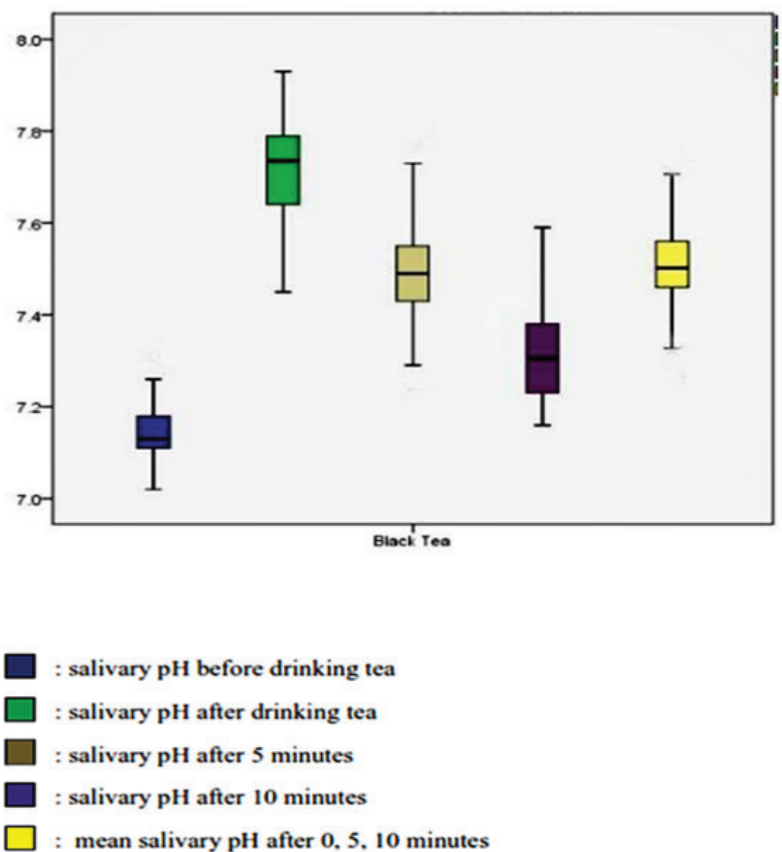

Figure 2 - box plot of mean salivary $\mathrm{pH}$ before and after drinking black tea.

Independent t-test revealed that there was a remarkable different between green and black tea at minutes of 0,5 and 10 after drinking tea $(\mathrm{p}=0.003,0.026$ and 0.019 , respectively) (table III).

Also, independent t-test showed that there was a significant different between green and black tea according to mean $\mathrm{pH}$ of all salivary samples after drinking tea $(\mathrm{p}=0.006)$ (table III). 
Table III - comparison of mean salivary $\mathrm{pH}$, after drinking green and black tea

\begin{tabular}{|cccc|}
\hline \multirow{2}{*}{ Time } & \multicolumn{2}{c}{ Mean \pm SD } & \\
& Green tea & Black tea & p-value* \\
\hline Immediately after drinking & $7.78 \pm 0.09$ & $7.71 \pm 0.12$ & 0.003 \\
\hline 5 min after drinking & $7.55 \pm 0.10$ & $7.50 \pm 0.12$ & 0.026 \\
\hline 10 min after drinking & $7.36 \pm 0.09$ & $7.31 \pm 0.10$ & 0.019 \\
\hline $\begin{array}{c}\text { Mean of 0,5 and 10 minutes } \\
\text { after drinking }\end{array}$ & $7.56 \pm 0.09$ & $7.51 \pm 0.10$ & 0.006 \\
\hline * Independent t-test. & & & \\
\hline
\end{tabular}

\section{DISCUSSION}

Dental caries is the most important reason for dental destruction, which is induced by $\mathrm{pH}$ changes after consumption of sweet foods. Since breaking down the carbohydrate by some oral microflora, shifts the salivary $\mathrm{pH}$ to an acidic range and demineralizes the dental enamel[4], every factor, which could increase oral $\mathrm{pH}$, might be effective in prevention or control of dental caries. In previous studies using tea influenced on control or prevention of dental caries [19, $21]$.

In this study, the salivary $\mathrm{pH}$ increased after drinking green and black tea, green tea had more effect on control of $\mathrm{pH}$ than black tea.

Similar results were observed in Srinidhi's study, which revealed that drinking of both types of tea altered salivary $\mathrm{pH}$ to alkaline range, although the increase of $\mathrm{pH}$ after consumption of green tea was remarkably more than black tea [19].

Also, Balappanavar's study showed that tea mouthwash increases salivary $\mathrm{pH}$, as $\mathrm{pH}$ shifts to alkaline range [22]. Other studies showed a significant increase in salivary $\mathrm{pH}$ after consumption of black tea, could be related to buffering capacity of this plant [23-25]. Correspondingly, in our study using black tea raised salivary $\mathrm{pH}$; however, this effect was remarkably less than that of green tea.

It seems that dropping of salivary flow rate and increasing of salivary acidity prepare a suitable environment for growing of oral, especially periodontal pathogens. One study demonstrated that green tea increases salivary flow rate and decreases acidity more than black tea and coffee. This finding suggests that daily consumption of green tea could be effective in prevention and even treatment of periodontal diseases[21] .

Moreover, another review article mentioned that drinking tea prevents dental caries. It is suggested that the protective effects of tea is related to its organic component more than fluoride [26], however, it was showed that fluoride of black tea has an acceptable binding to the teeth surfaces[27] .

Another study demonstrated that daily using of mouthwash of fluoride or green tea leads to reduce of some salivary bacterial colonies[28], although the cario-static effects of green tea extract is less than fluoride or chlorhexidine solutions[29] .

Green tea contains flavonoids, tannins, and a few amounts of fluoride and mineral components and some vitamins. Some antioxidants and anti-microbial components of green tea are established to be effective in prevention of caries and increase of healthy of the teeth [30-33].

According to the studies, catechin, fluoride and polyphenols of green tea are the causative factors of decreasing of dental caries. Green tea, especially catechin decreases the production of acid by streptococcus mutans and regulates salivary $\mathrm{pH}$ within the normal range, which is unsuitable for activity of cariogenic bacteria $[11,16,34]$.

Demir et al. showed that green tea has the least effects on shift of salivary $\mathrm{pH}$ to acidic range compared to other drinks such as Coca and effect of green tea on change of the salivary $\mathrm{pH}$ to the alkaline range is more than other beverages [35].

Briefly, different studies showed that consumption of black and green tea without any sweet additives leads to a decrease in incidence of caries, which is similar to the present study. This anti- cariogenic activity of tea could be 
related to some tea gradients such as fluoride and polyphenols and catchins, as well as, an increase in the buffering capacity. All subjects in the present study were young male students, which is one of limitations of this study. Another limitation was evaluation of salivary $\mathrm{pH}$ before and after drinking two kinds of tea; it is suggested to compare the results with placebo liquid to better evaluation of the results. Also, it is recommended to assess the effects of tea on dental caries with larger sample size belong to different genders and age groups, for longer time for proper interpretation of effects of tea on oral cavity.

\section{CONCLUSION}

This study revealed that using black and green tea increases salivary $\mathrm{pH}$. The results suggest some beneficial effects of drinking tea in providing an alkaline environment in oral cavity.

\section{Acknowledgments}

We thank the Vice Chancellor for Oral and Dental Diseases Research Center of Zahedan University of Medical Sciences for supporting this research. The results described in this paper was part of a (D.D.S) student thesis

\section{Funding}

This study was partially supported by Vice Chancellor for Oral and Dental Diseases Research Center of Zahedan University of Medical Sciences.

\section{Conflict of interest}

The authors have no proprietary, financial, or other personal interest of any nature or kind in any product, service, and/or company that is presented in this article.

\section{Regulatory Statement}

This study was conducted in accordance with all the provisions of the local human subject's oversight committee guidelines and policies of: ethical committee of Zahedan University of Medical Sciences. The approval code for this study is: 93.4.1223.

\section{REFERENCES}

1. Tanner ACR, Kressirer CA, Rothmiller S, Johansson I, Chalmers NI. The caries microbiome: implications for reversing dysbiosis. Adv Dent Res. 2018 Feb;29(1):78-85. doi: 10.1177/002203451773649

2. Kianoush N, Adler CJ, Nguyen KA, Browne GV, Simonian M, Hunter N. Bacterial profile of dentine caries and the impact of $\mathrm{pH}$ on bacterial population diversity. PLoS One. 2014 Mar 27;9(3):e92940. doi: 10.1371/journal. pone.0092940

3. Philip N, Leishman S, Walsh L. Potential role for natural products in dental caries control. Oral Health Prev Dent. 2019;17(5):479-85. doi: 10.3290/j.ohpd. a427

4. Agarwal S, Navit S, Khan SA, Sharma A, Jaebeen S, Grover N. Salivary pH: Its Implications for Better Pediatric Oral Health. Int J of Oral Health Med Res. 2019;6(1);29-33.

5. Ahmadi-Motamayel F, Goodarzi MT, Hendi SS, Kasraei S, Moghimbeigi A. Total antioxidant capacity of saliva and dental caries. Med Oral Patol Oral Cir Bucal. 2013 Jul 1;18(4):e553-6. doi: 10.4317/medoral.18762.

6. Fudali-Walczak M, Raba G, Obłoza B. Saliva pH testing in predicting dental caries in children aged 7-10 years. Prz Med Uniw Rzesz Inst Leków 2015; 13 (2):90-9

7. Ho CT, Lin JK, Shahidi F. Tea and tea products: chemistry and healthpromoting properties.: Boca Raton: CRC Press; 2008.

8. Koo MW, Cho CH. Pharmacological effects of green tea on the gastrointestinal system. Eur JPharmacol, 2004.500(1-3): 177-85.

9. Mahmood T, Akhtar N, Khan BA, The morphology, characteristics, and medicinal properties of Camellia sinensis tea. J Med Plants Res, 2010; 4(19):2028-33

10. Khan N, Mukhtar H. Tea and health: studies in humans. Curr pharmI Design. 2013; 19(34):6141-7.

11. Hamilton-Miller JMT. Anti-cariogenic properties of tea (Camellia sinensis). J Med Microbiol. 2001 Apr;50(4):299-302. doi: 101099/0022-1317-50-4-299.

12. Yang CS, Wang H. Cancer preventive activities of tea catechins. Molecules. 2016 Dec 9;21(12):1679. doi: 10.3390/molecules21121679.

13. Kuriyama S, Shimazu T, Ohmori K, Kikuchi N, Nakaya N, Nishino Y, et al. Green tea consumption and mortality due to cardiovascular disease, cancer, and all causes in Japan: the Ohsaki study. JAMA. 2006 Sep 13;296(10):1255-65. doi: 10.1001/jama.296.10.1255

14. Abe SK, Saito E, Sawada N, Tsugane S, Ito H, Lin Y, et al. Green tea consumption and mortality in Japanese men and women: a pooled analysis of eight population-based cohort studies in Japan. Eur J Epidemiol. 2019 Oct;34(10):917-26. doi: 10.1007/s10654-019-00545-y.

15. Awadalla HI, Ragab MH, Bassuoni MW, Fayed MT, Abbas MO. A pilot study of the role of green tea use on oral health. Int J Dent Hyg. 2011 May;9(2):110-6. doi: 10.1111/j.1601-5037.2009.00440.x

16. Hirasawa $M$, Takada K, Otake S. Inhibition of acid production in dental plaque bacteria by green tea catechins. Caries Res. 2006;40(3):265-70. doi: 10.1159/000092236.

17. Narotzki B, Reznick AZ, Aizenbud D, Levy Y. Green tea: a promising natural product in oral health. Arch Oral Biol. 2012 May;57(5):429-35. doi: 10.1016/j. archoralbio.2011.11.017. 
18. Bowen $\mathrm{WH}, \mathrm{KoO} \mathrm{H}$. Biology of Streptococcus mutans-derived glucosyltransferases: role in extracellular matrix formation of cariogenic biofilms. Caries Res. 2011;45(1):69-86. doi: 10.1159/000324598.

19. Srinidhi PB, Basha Sakeenabi, Naveen Kumar PG, Prashant GM, Sushanth VH, Imranulla Mohammed. Effect of two different commercially available tea products on salivary $\mathrm{pH}$ : A randomized double blinded concurrent parallel study. Dent Med Res. 2014;2(2):39-42. doi: 10.4103/2348-1471.143330

20. Shirzaiy M, Aiub Rigi Ladiz M, Dalirsani Z, Dehghan Haghighi J, Nakhaii A. Evaluation of Salivary Total Antioxidant Capacity in Smokers with Severe Chronic Periodontitis, Int J High Risk Behav Addict. 2017 ; 6(3):e59486. doi: 10.5812/ijhrba.59486.

21. Masoumi S, Setoudehmaram S, Golkari A, Tavana Z. Comparison of pH and flow rate of saliva after using black tea, green tea and coffee in periodontal patients and normal group. 2016. J Dent School 2016;34(4):235-43

22. Balappanavar AY, Sardana V, Singh M. Comparison of the effectiveness of $0.5 \%$ tea, $2 \%$ neem and $0.2 \%$ chlorhexidine mouthwashes on oral health: a randomized control trial. Indian JDent Res. 2013 Jan-Feb;24(1):26-34. doi: 10.4103/0970-9290.114933

23. Arab H, Maroofian A, Golestani S, Shafaee H, Sohrabi K, Forouzanfar A Review of The therapeutic effects of Camellia sinensis (green tea) on oral and periodontal health. J Medic Plants Res. 2011;5(23):5465-9.

24. Gul P,Akgul N, Seven N. Anticariogenic potential of white cheese, xylitol chewing gum, and black tea. Eur J Dent. 2018 Apr-Jun;12(2):199-203. doi: 10.4103/ejd.ejd 4 _18.

25. Mardiati E, Aryati E, Wiradona I, Santoso B. The effect of black coffee and tea consumption to saliva degree of acidity in preventing tooth decay. ARC J Dent Sci. 2017; 2(3):11-3

26. Goenka P, Sarawgi A, Karun V, Nigam AG, Dutta S, Marwah N. Camellia sinensis (Tea): Implications and role in preventing dental decay. Pharmacognosy reviews. 2013;7(14): 152.
27. Simpson A, Shaw L, Smith AJ. The bio-availability of fluoride from black tea J Dent. 2001 Jan;29(1):15-21. doi: 101016/s0300-5712(00)00054-3.

28. Tehrani MH, Asghari G, Hajiahmadi M. Comparing Streptococcus mutans and Lactobacillus colony count changes following green tea mouth rinse or sodium fluoride mouth rinse use in children (Randomized double-blind controlled clinical trial). Dent Res J (Isfahan). 2011Dec;8(Suppl 1):S58-63.

29. Jazaeri M, Pakdek F, Rezaei-Soufi L, Abdolsamadi H, Rafieian N. Cariostatic effect of green tea in comparison with common anticariogenic agents: an in vitro study. J Dent Res Dent Clin Dent Prospects. 2015 Winter;9(1):44-8. doi: 10.15171/joddd.2015.009

30. Bérubé-Parent S, Pelletier C, Doré J, Tremblay A. Effects of encapsulated green tea and Guarana extracts containing a mixture of epigallocatechin-3gallate and caffeine on $24 \mathrm{~h}$ energy expenditure and fat oxidation in men. $\mathrm{Br}$ J Nutr. 2005 Sep;94(3):432-6. doi: 10.1079/bjn20051502

31. Ferrara L, Montesano D, Senatore A. The distribution of minerals and flavonoids in the tea plant (Camellia sinensis). Farmaco. 2001MayJul:56(5-7):397-401. doi: 101016/s0014-827x(01)01104-1

32. du Toit R, Volsteedt Y, Apostolides Z. Comparison of the antioxidant content of fruits, vegetables and teas measured as vitamin C equivalents. Toxicology. 2001Sep 14;166(1-2):63-9. doi:10.1016/s0300-483x(01)00446-2

33. Serafini $M$, Ghiselli A, Ferro-Luzzi A. In vivo antioxidant effect of green and black tea in man. Eur J Clin Nutr. 1996 Jan;50(1):28-32

34. Xu X, Zhou XD, Wu CD. The tea catechin epigallocatechin gallate suppresses cariogenic virulence factors of Streptococcus mutans. Antimicrob Agents Chemother. 2011Mar:55(3):1229-36. doi:10.1128/AAC.01016-10

35. Demir T, Demir H, Gorler 0, Ozden S, Dogan D0, Tugut F et al. The effects of some drinks on saliva pH. J Interdiscipl Med Dent Sci. 2017;5(216):2

\section{Zohreh Dalirsani}

(Corresponding address)

Oral and Maxillofacial Diseases Research Center, Mashhad University of Medical Sci-

ences, Mashhad, Iran

Email: zdalirsani@gmail.com

Date submitted: 2020 Aug 23

Accept submission: 2020 Nov 11 